\title{
LARANGAN DEMO OLEH SULTAN HAMENGKU BUWONO X PASCA DEMO 8 OKTOBER 2020 DI YOGYAKARTA
}

\author{
${ }^{1}$ Toni Kurniawan, S.H. \\ Hukum Tata Negara, UIN Sunan Kalijaga Yogyakarta \\ Toniwe605@gmail.com \\ ${ }^{2}$ Anna Zakiah Derajat, S.Hum \\ Konsentrasi Kajian Timur Tengah, Pascasarjana UIN Sunan Kalijaga Yogyakarta \\ annazakiyyahderajat@gmail.com
}

\begin{abstract}
This paper aims to explain the implementation of Article 5 of Law Number 9 of 1998 concerning Freedom to Express Opinions after the demonstration on October 8, 2020 in Yogyakarta, thus giving birth to Sri Sultan Hamengku Buwono X's appeal regarding demonstrations in the perspective of mas\}lah\}ah. This type of research is literature research by conducting various studies that are considered credible with the primary source studied. This research results in a conclusion that freedom to express opinions in public is part of the basis of democracy, which has a role in eradicating corruption, gaps in government, and a last resort in conveying an aspiration. In implementing Article 5 of Law Number 9 of 1998 at the demonstration that took place on October 8, 2020 in Yogyakarta, restrictions are still needed so as not to conflict with Islamic law and laws. The demonstration in Yogyakarta led to anarchism, which led to a response from Sultan HB X. The appeal issued by Sultan HB X can be justified because it considers many things, one of which is security, safeguarding public facilities, and order. This appeal also does not mean to limit, eliminate people's rights, and prohibit them from expressing their aspirations.
\end{abstract}

Key words: demonstration, mas\}lah\}ah, appeal of Sultan HB X, anarchist, freedom of opinion

\begin{abstract}
Abstrak
Tulisan ini bertujuan untuk menjelaskan tentang implementasi Pasal 5 Undang-Undang Nomor 9 Tahun 1998 Tentang Kemerdekaan Menyampaikan Pendapat pasca terjadinya demonstrasi pada tanggal 8 Oktober 2020 di Yogyakarta, sehingga melahirkan himbauan Sri Sultan Hamengku Buwono $X$ terkait demonstrasi tersebut dalam perspektif mas\}lah\}ah. Jenis penelitian ini adalah penelitian pustaka dengan melakukan berbagai pengkajian yang dianggap kredibel dengan sumber primer yang diteliti. Penelitian ini menghasilkan suatu kesimpulan bahwa kemerdekaan menyampaikan pendapat di muka umum merupakan sebagian dari adanya dasar demokrasi, yang memiliki peran untuk melakukan pemberantasan korupsi, adanya ketimpangan dalam pemerintahan, dan jalan terakhir dalam menyampaikan sebuah aspirasi. Dalam mengimplementasikan Pasal 5 UU Nomor 9 Tahun 1998 pada aksi demonstrasi yang terjadi pada tanggal 8 Oktober 2020 di Yogyakarta, tetap diperlukan batasan-batasan
\end{abstract}


agar tidak bertentangan dengan hukum Islam dan undang-undang. Adanya demonstrasi di Yogyakarta tersebut berujung anarkis, sehingga mendapatkan tanggapan dari Sultan HB X. Himbauan yang dikeluarkan oleh Sultan HB X tersebut jika ditelaah dalam perspektif mas lah $\} a h$, dapat dibenarkan karena mempertimbangkan banyak hal, salah satunya adalah keamanan, penjagaan fasilitas umum, dan ketertiban. Adanya himbauan ini juga bukan bermaksud untuk membatasi, menghilangkan hak-hak masyarakat, dan melarang mereka dalam menyampaikan aspirasinya.

Kata kunci: demonstrasi, mas\}lahłah, himbauan Sultan HB X, anarkis, kebebasan berpendapat.

\section{Pendahuluan}

Semakin dewasanya suatu bangsa, maka kemerdekaan untuk menyampaikan pendapat semakin dihormati dan dilindungi. Hal ini telah tercatat dalam Pasal 5 Undang-undang Nomor 9 Tahun 1998 Tentang Kemerdekaan Menyampaikan Pendapat di Muka Umum. Dalam pasal tersebut disebutkan bahwa "setiap warga negara yang menyampaikan pendapat di muka umum berhak untuk (a) mengeluarkan pikiran secara bebas; (b) memperoleh perlindungan hukum. ${ }^{1}$ Salah satu bentuk penyampaian pendapat di muka umum adalah dengan diadakannya aksi demonstrasi. Demonstrasi sendiri berasal dari bahasa Inggirs, yaitu demonstrate yang memiliki makna mempertunjukkan, demonstrasi, atau mempertontonkan. Dapat disimpulkan bahwa demonstrasi merupakan suatu kegiatan yang dilakukan oleh seseorang atau lebih dengan tujuan untuk mengeluarkan pendapat yang ada dalam pikiranya melalui berbagai cara, seperti lisan, tulisan-tulisan, ataupun yang lainnya secara terbuka di tempat umum. ${ }^{2}$

Salah satu aksi demo dengan tujuan untuk mengeluarkan pendapat adalah aksi demo massa tolak Undang-undang Omnibus Law pada tanggal 8 Oktober tahun 2020 yang terjadi di berbagai daerah, salah satunya di DIY Yogyakarta. Aliansi Rakyat Bergerak yang di dalamnya terdiri dari mahasiswa dan berbagai elemen masyarakat berupaya untuk melakukan aksi demonstrasi dalam penolakan Undang-undang Cipta Kerja. Pada mulanya, aksi demonstrasi ini masih terpantau aman dan terkendali, sampai

${ }^{1}$ DPR RI, “Undang-Undang Republik Indonesia Nomor 9 Tahun 1998 Tentang Kemerdekaan Menyampaikan Pendapat di Muka Umum” (Jakarta, 1998).

${ }^{2}$ Budiman Tanuredjo, Pasung Kebebasan: Menelisik Kelahiran Undang-Undang Unjuk Rasa (Jakarta: Lembaga Studi dan Advokasi Masyarakat (ELSAM), 1991), 250. 
ada sekelompok massa aksi yang mencoba untuk memasuki gedung DPRD DIY dan diadang oleh polisi tepat di depan pintu gerbang gedung tersebut. Oleh sebab itu, demonstrasi yang dilakukan pada tanggal 8 Oktober tahun 2020 itu berakhir dengan kericuhan.

Aksi demonstrasi ini tentu mengakibatkan sejumlah fasilitas di Kantor DPRD DIY, Jalan Malioboro, serta beberapa tempat di Kota Yogyakarta mengalami banyak kerusakan. Jika dikalkulasikan, taksiran kerugian yang diakibatkan oleh kerusakan tersebut mencapai ratusan juta rupiah. Pasca terjadinya aksi demonstrasi ini, akhirnya Sri Sultan Hamengku Buwono (HB) X angkat bicara. Raja Keraton Yogyakarta sekaligus Gubernur DIY tersebut sangat menyesalkan aksi anarkis yang terjadi pada demonstrasi 8 Oktober 2020 tersebut. Menurut Sri Sultan, tindakan anarkis tersebut telah melanggar karakter warga Yogyakarta. Dalam menyikapi hal tersebut, Gubernur DIY Sri Sultan Hamengku Buwono X meminta kepada para demonstran untuk tidak lagi mengerahkan massa seperti pada demonstrasi tanggal 8 Oktober 2020. Sultan mengungkapkan kepada awak media, yaitu:

"Yogyakarta dengan masyarakatnya tidak pernah memiliki itikad untuk membangun anarki, khususnya untuk aktivitas-aktivitas yang dilakukan oleh kelompok-kelompok masyarakat. Untuk itu, saya Hamengku Buwono X mengimbau dan berharap kepada warga, kelompok-kelompok masyarakat, bukan karakter kita untuk berbuat anarkis di kotanya sendiri. ${ }^{13}$

Dalam pandangan Islam, demonstrasi memang tidak dijelaskan secara terperinci. Tetapi, pada pelaksanaannya haruslah didasarkan pada aspek positif dan negatifnya telebih dahulu. Islam mengajarkan bahwa upaya menyampaikan suatu ide, gagasan, atau berita kebenaran (amar makruf nahi mungkar), tetap harus dilihat dari berabgai sisi. Jadi, sangat tidak dibenarkan menyampaikan pendapat tersebut dengan menggunakan cara kekerasan. Adanya tindakan kekerasan dan perusakan saat demonstrasi 8 Oktober 2020 tersebut, jika dilihat dalam perspektif mas\}lah\}ah tentu saja sangat bertentangan. Hal ini disebabkan oleh tindakan dalam demonstrasi tersebut

\footnotetext{
${ }^{3}$ Tribun Jogja, "Demo Omnibus Law di Yogyakarta, Pernyataan Sri Sultan HB X Hingga Sikap Warga Kecam Aksi Anarkis,” Jum'at, Oktober 2020, https://jogja.tribunnews.com/2020/10/09/demoomnibus-law-di-yogyakarta-pernyataan-sri-sultan-hb-x-hingga-sikap-warga-kecam-aksi-anarkis?page=4 .
} 
tidak dilakukan dengan cara-cara yang baik, tidak mencerminkan demonstrasi yang bisa menegakkan, dan menentramkan masyarakat.

Definisi mas llah\}ah sendiri menurut 'urf atau pemahaman umum yang telah berkembang di masyarakat adalah sebab-sebab yang akan membawa pada kemaslahatan. Sedangkan, menurut pandangan hukum Islam, maslahat merupakan sebab yang dapat membawa akibat bagi tercapainya suatu tujuan sesuai syariat Islam, baik dalam bentuk ibadah maupun muamalah. Maslahat juga terbagi menjadi dua, yaitu maslahat yang memang dikehendaki oleh syariat sebagai prerogatif-Nya dan maslahat yang dimaksudkan untuk mencapai kemaslahatan umat manusia. ${ }^{4}$ Ada beberapa kaidah yang berkaitan dengan mas\}lah\}ah, yaitu (1) daru al-mafasid huqaz\{|amu 'ala> jalb almas $\} a>l i h\},{ }^{5}$ (2) jalb al-mas\}a>lih\} huqaz|amu 'ala> daf'u al-mafa>sid, ${ }^{6}$ (3) la> d)arar wala $>$ d\}ira $>r$, (4) al-d\}arar yusa $>l .^{7}$

Jenis penelitian ini adalah penelitian kualitatif. Peneliti akan memfokuskan pada pengkajian berbagai literatur yang dianggap relevan pada penelitian ini. Dalam penelitian ini akan mengkaji Pasal 5 Undang-Undang Nomor 9 Tahun 1998 Tentang Kemerdekaan Menyampaikan Pendapat di Muka Umum yang dikaitkan dengan permasalahan demonstrasi tolak UU Omnibus Law pada tanggal 8 Oktober 2020 di Yogyakarta dengan menggunakan perspektif mas\}lah\}ah.

Dalam sebuah artikel jurnal, Ujang Chandra $\mathrm{S}^{8}$ menjelaskan bahwa kemerdekaan berekspresi merupakan hak bagi setiap warga negara yang bertujuan untuk menginformasikan pikirannya melalui berbagai cara, seperti lisan maupun tertulis dengan bebas dan bertanggung jawab. Dalam penelitiannya juga dijelaskan bahwa

${ }^{4}$ Mustafa Zaid, Al-Maslahah fi al-Tasyri' al-Islami wa Najm ad-Din at-Tufi (Beirut: Dar al-Fikr al-Arabiy, 1974), 211.

5 Yahya Khusnan Mansur, Ulasan Nazam Qawaid Fiqhiyyah al-Faraid al-Bahiyyah (Tambak Beras Jombang: Pustaka al-Muhibbin, 2009), 88.

${ }^{6}$ Abdul Haq, Formulasi Nalar Fiqh Telaah Konseptual (Surabaya: Khalista, 2006), 237.

${ }^{7}$ Yahya Khusnan Mansur, Ulasan Nazam Qawaid Fiqhiyyah al-Faraid al-Bahiyyah, 81.

${ }^{8}$ Ujang Chandra S, "Hakikat Hak Kebebasan Menyampaikan Pendapat di Muka Umum," Jurnal Komunikasi Hasil Pemikiran dan Penelitian 3, no. 1 (April 2017). 
penyampaian pendapat secara lisan bisa dengan cara berbicara, berdialog, dan berdiskusi. Sedangkan, jika penyampaian pendapat itu secara tertulis, maka dapat menggunakan berbagai cara, seperti petisi, pamflet, gambar, brosur, poster, spanduk, dan selebaran.

Selain itu, Siti Tatmainul Qulub ${ }^{9}$ juga menjelaskan dalam artikelnya, yaitu Islam telah memberikan kebebasan kepada umatnya untuk menyampaikan pendapat. Tetapi, harus dengan cara yang baik. Islam juga telah membatasi substansi apa yang perlu disampaikan, yaitu dengan menyajikan berbagai informasi yang dianggap bermanfaat dan terbukti kebenarannya. Ada juga artikel yang ditulis oleh Muhammad Aminullah ${ }^{10}$ yang menjelaskan bahwa demonstrasi itu hadir sebagai salah satu bentuk protes terhadap banyaknya kebijakan yang dianggap tidak berpihak kepada rakyat. Kemudian, artikel yang ditulis oleh Muhammad Gazali Rahman. ${ }^{11}$ Dalam penelitiannya ia menjelaskan bahwa pada realitasnya setiap kegiatan demonstrasi itu tetap akan melahirkan kata-kata kotor yang dianggap menjadi lagu wajib yang harus dengan penuh semangat. Hal ini dijadikan sebagai jalan untuk menghujat, menghasut, memprovokasi, dan mencaci maki hingga berujung pada anarki.

Kajian yang dilakukan di atas menunjukkan satu kesamaan, yaitu yang fokus mengkaji demonstrasi yang dijadikan sebagai wadah dalam menyampaikan aspirasi. Namun, kajian-kajian tersebut masih sangat umum, sehingga peneliti memutuskan untuk melakukan kajian demonstrasi pada tanggal 8 Oktober 2020 di Yogyakarta, sehingga lahirnya pelarangan yang dibuat oleh Sri Sultan Hamengku Buwono X akibat demonstrasi tersebut. Pembahasan ini akan difokuskan pada pengkajian Pasal 5 UU Nomor 9 Tahun 1998 terhadap demonstrasi 8 Oktober 2020 di Yogyakarta. Selain itu,

${ }^{9}$ Siti Tatmainul Qulub, "Batasan Kebebasan Berpendapat dalam Menyampaikan Argumentasi Ilmiah di Media Sosial Perspektif Hukum Islam," Jurnal Al-Jinayah: Jurnal Hukum Pidana Islam 4, no. 2 (Desember 2018).

10 Muhammad Aminullah, "Demonstrasi dalam Perspektif Hadis," Jurnal El-Hikam: Jurnal Pendidikan dan Kajian Keislaman VII, no. 2 (Juli 2014).

11 Muhamamd Gazali Rahman, "Unjuk Rasa Versus Menghujat (Analisis Deskriptif Melalui Pendekatan Hukum Islam),” Jurnal Hunafa: Jurnal Studia Islamika 122, no. 2 (Desember 2015). 
penelitian ini juga akan mengkaji bagaimana mas\}lah\}ah memandang pelarangan demonstrasi oleh Sultan Hamengku Buwono X.

\section{Pembahasan}

\section{Pelarangan Demonstrasi Oleh Sultan Hamengku Buwono X Pasca Demo 8 Oktober 2020 di Yogyakarta}

Adanya pelarangan demonstrasi oleh Sultan Hamengku Buwono $\mathrm{X}$ pasca terjadinya demonstrasi pada tanggal 8 Oktober 2020 di Yogyakarta ini tidak sewenangwenang diputuskan oleh Sultan HB X. Keputusan tersebut dibuat berdasarkan berbagai pertimbangan yang sangat mendominasi, seperti banyaknya kerusakan saat terjadinya demonstrasi anarkis di Yogyakarta dan adanya pelanggaran tata nilai budaya yang telah diterapkan di Kota Yogyakarta.

\section{Perusakan Fasilitas Saat Terjadinya Demonstrasi}

Demonstrasi massa buruh, aktivis dari berbagai organisasi, mahasiswa, serta masyarakat sipil yang digelar pada tanggal 8 Oktober 2020 dengan tujuan untuk menolak pengesahan Omnibus Law UU Cipta Kerja ini dilatarbelakangi oleh pengesahan UU Omnibus Law yang dilakukan oleh DPR RI pada sidang paripurnanya tanggal 5 Oktober 2020. UU Cipta Kerja yang sangat disoroti oleh masyarakat saat itu ada pada peraturan tentang ketenagakerjaan. Di mana sejumlah pasal terkait hubungan kerja, PHK, upah, hingga pesangon yang dianggap dapat merugikan para buruh. Berbagai aturan baru tentang perizinan investasi pun dianggap sangat bermasalah, sehingga akan berdampak buruk bagi lingkungan masyarakat.

Adanya demonstrasi tolak UU Cipta Kerja Omnibus Law di Yogyakarta ini berakhir dengan kericuhan. Para demonstran yang terlibat kontak fisik dan saling lempar di depan Kantor DPRD DIY terdiri dari buruh, masyarakat sipil, mahasiswa, hingga pelajar. Semburan air dari beberapa kendaraan water canon, tembakan gas air mata, lembaran batu dan botol telah mewarnai aksi tersebut. ${ }^{12}$ Penolakan gerakan

\footnotetext{
12 Tribun Jogja, "Demo Omnibus Law di Yogyakarta, Pernyataan Sri Sultan HB X Hingga Sikap Warga Kecam Aksi Anarkis.”
} 
masyarakat sipil terhadap Omnibus Law UU Cipta Kerja ini didasarkan dengan berbagai alasan, selain adanya poin-poin yang dianggap banyak merugikan kaum buruh, penyusunan UU ini pun dianggap sangat tidak partisipatif dengan tidak dilibatkannya kaum pekerja yang nantinya menjadi salah satu yang terdampak dari Omnibus Law ini. Konfederasi Serikat Pekerja Seluruh Indonesia (KSPSI) telah menyatakan bahwa para buruh tidak dilibatkan dalam penyusunan UU Omnibus Law ini. Bahkan, Presiden KSPI juga telah memberikan saran kepada pihak pemerintah untuk berkomunikasi langsung dengan para buruh sebelum memutuskan perumusan UU Omnibus Law ini. ${ }^{13}$

Kerusuhan yang terjadi pada demonstrasi 8 Oktober 2020 di Yogyakarta ini telah merusak sejumlah kendaraan polisi dan fasilitas umum, bahkan salah satu restoran legendaris, yaitu Legian Resti yang lokasinya tepat di sebelah gedung DPRD DIY pun ikut terbakar. Kerusakan parah akibat kebakaran ini mencapai kerugian sekitar lima ratus juta. Peristiwa kebakaran tersebut terjadi bermula dari adanya seseorang yang tertangkap CCTV tengah melakukan pelemparan bom molotov, sehingga mengenai Legian Resto tersebut. ${ }^{14}$

Selain itu, ada beberapa daftar kerusakan materil di DPRD DIY dari Polda DIY, yaitu 1 SPM terbakar 100\% yang berlokasi di jalan depan DPRD DIY, 2 mobil Patroli Polres Kota Yogyakarta yang kacanya pecah, 1 mobil Kijang Nopol AB 1713 PK, 1 buah mobil DitSamapta Water Canon Polda DIY kaca pecah, 1 mobil ambulan dari DokPol Polresta Yogyakarta kaca depan dan kaca samping yang pecah, 1 mobil Izuzu Dina Korp Bribmob dengan kaca pecah, 1 SPM Shogun Nopol AB 5273 IY, 1 SPM NMaz Nopol AB 5664 ZK, 2 SPM Honda Babinkamtibmas, 2 pos satpam kaca pecah dan pintu yang rusak, 1 SPM Honda Astrea Nopol 6809 SA, bagian kaca pintu dan

\footnotetext{
${ }^{13}$ Muhamamd Fakhrur Razy dan Muhammad Fedryansyah, "Konflik Gerakan Masyarakat Sipil dan Pemerintah dalam Proses Penyusunan Rancangan Undang Undang Omnibus Law," Jurnal Kolaborasi Resolusi Konflik 2, no. 2 (2020): 75.

$\begin{array}{ccc} & 14 \text { Kompas, "Mengungkap Fakta Restoran Legian di Malioboro Terbakar } & \text { Saat Kerusuhan di } \\ \text { DPRD } & \text { KIY," } & \text { Ompas.com, }\end{array}$ https://yogyakarta.kompas.com/read/2020/10/10/14400091/mengungkap-fakta-restoran-legian-dimalioboro-terbakar-saat-kerusuhan-di?page=all.
} 
jendela di kantor DPRD DIY pecah, fasilitas cuci tangan berserakan di jalan, ramburambu lalu lintas, dan pembatas jalan yang rusak. ${ }^{15}$

Berbagai fasilitas yang dirusak saat adanya demonstrasi 8 Oktober 2020 ini membuat Sri Sultan Hamengku Buwono X ikut berkomentar. Sultan tidak melarang jika ada mahasiswa, masyarakat, pelajar yang memang sedang menuntut ilmu di Yogyakarta ketika ingin mengikuti aksi demonstrasi. Tetapi, aksi demonstrasi tersebut harus dilakukan dengan cara yang baik dan tertib, sehingga tidak dilakukan secara anarkis dalam menyampaikan aspirasinya. Menurut Sultan Hamengku Buwono X, masyarakat Yogyakarta sendiri tidak pernah mempunyai itikad untuk membangun sebuah anarki, kerusuhan, bahkan perusakan fasilitas yang ada untuk aktivitas-aktivitas yang dilakukan oleh kelompok-kelompok masyarakat. Karena, tindakan anarkis tersebut tidak melambangkan karakter warga Yogyakarta.

Dalam menyikapi aksi demonstrasi tersebut, warga Yogyakarta menyatakan sikapnya, yaitu pertama, masyarakat Yogyakarta mengutuk dan mengecam keras adanya demonstrasi massa yang berujung kekerasan; kedua, masyarakat meminta kepada para aparat yang berwenang untuk terus mengusut dan melanjutkan proses hukum para pelaku tindak kekerasan. Ketiga, masyarakat juga menyerukan kepada para demonstran untuk menyampaikan pendapatnya secara tertib dan konstitusional, menghormati hak-hak sipil masyarakat lainnya, khususnya keapda para pemilik usaha yang mengalami dampak dari adanya aksi massa tersebut. Keempat, masyarakat DIY akan siap turun tangan dalam menghadapi massa aksi yang bertindak anarkis dan mengganggu kenyamanan warga DIY. Kelima, masyarakat DIY juga meminta agar pemerintah segera merespons dinamika politik yang terjadih di tengah masyarakat dengan sigap, mengedepankan prinsip keadilan, serta mengutamakan kepentingan umum. ${ }^{16}$

${ }^{15}$ Kumparan, "Daftar Kerusakan Demo Yogya: Cafe Terbakar hingga Mobil Polisi," Kumparan NEWS, Oktober 2020, https://kumparan.com/kumparannews/daftar-kerusakan-demo-yogya-cafe-terbakarhingga-mobil-polisi-1uLvpTwRUmQ.

\footnotetext{
16 Tribun Jogja, "Pesan Sri Sultan Hamengku Buwono X: Kalau Mau Demo, Silahkan. Asal, Tidak Melakukan Perusakan," TribunJogja.com, 24 September 2019, https://jogja.tribunnews.com/2019/09/24/pesan-sri-sultan-hamengku-buwono-x-kalau-mau-demosilahkan-asal-tidak-melakukan-perusakan.
} 


\section{Pelanggaran Tata Nilai Budaya Yogyakarta}

Adanya demonstrasi anarkis di Yogyakarta yang digelar pada tanggal 8 Oktober 2020 lalu, tentu saja sangat bertentangan dengan perilaku masyarakat Yogyakarta yang dikenal dengan ramah, toleran, dan tidak ricuh. Dalam pengamatan peradaban saat ini, tercipta sebuah ekspetasi di mana manusia zaman sekarang memiliki nilai-nilai tolerasi yang tinggi terhadap gagasan dan perilaku orang lain yang dianggap berbeda dengan dirinya. Asumsi ini semakin kuat, karena setiap orang baik laki-laki maupun perempuan diperbolehkan untuk hidup dengan cara mereka masing-masing. Oleh sebab itu, hal ini melahirkan tumbuhnya multikuturalisme yang memungkinkan banyak orang untuk memiliki beragam pilihan dengan bebas, serta adanya dukungan dari masyarakat atas keberagamannya. ${ }^{17}$

Dilihat dari aspek budaya perilaku masyarakat Yogyakarta, sebetulnya tidak ada yang khusus karena tetap saja mirip dengan orang Jawa pada umumnya. Tetapi Kota Yogyakarta sendiri merupakan sebuah ladang subur bagi tumbuhnya berbagai kelompok toleran, baik secara individu maupun kelompok interfaith dialogue yang telah tersebar di berbagai tempat. Mungkin, hal inilah yang menjadi pembeda Kota Yogyakarta dengan tempat lain di Pulau Jawa.

Di Yogyakarta sendiri, adanya konflik, kekerasan, kericuhan dalam skala besar sangat jarang terjadi. Kalau pun memang ada, kejadian tersebut akan berlalu begitu cepat. Salah satu hal yang menyebabkan tidak terjadinya konflik di daerah ini adalah karena kuatnya kultur rembukan atau yang dikenal dengan istilah dialog, baik dilakukan secara formal maupun non-formal. Kultur dialog ini tidak hanya muncul di dalam ruang hampa, tetapi datang bersamaan dengan adanya proses transformasi sosial yang terjadi di masyarakat Yogyakarta. Kultur tersebut dijadikan sebagai jaminan dari kohesivitas sosial masyarakat Yogyakarta, yang kental dengan budaya-budaya penyangganya.

Hal ini juga terbukti ketika terjadinya demonstrasi anarkis pada tanggal 8 Oktober 2020 lalu. Pada saat itu, jajaran pemerintahan Yogyakarta akhirnya melakukan

17 Zaenal Abidin Eko Putro, "Ketahanan Toleransi Orang Jawa: Studi Tentang Yogyakarta Kontemporer," Jurnal Sosiologi 15, no. 2 (Juli 2010): 16. 
dialog dengan para demonstran. Namun, adanya dialog tersebut tidak menjadikan demonstran untuk berlaku tertib dan menghentikan aksi demo anarkisnya di sekitar wilayah Malioboro dan gedung DPRD DIY. Kemudian, pada tanggal 2 November 2020, Forum Badan Eksekutif Mahasiswa (BEM) DIY beritikad baik untuk menghadap Sri Sultan Hamengku Buwono X di Kepatihan. Pembahasan saat itu terkait adanya klarifikasi tidak terlibatnya kelompok mahasiswa dalam aksi kerusuhan pada demonstrasi UU Omnibus Law Cipta Kerja di Kantor DPRD DIY. Gabungan BEM DIY ini juga menyatakan tidak berafiliasi dengan berbagai kepentingan politik praktif dari pihak mana pun, serta mengecam adanya tindakan represif dalam aksi demonstrasi 8 Oktober 2020 itu. Sebab, pada hakikatnya demonstrasi merupakan jalan terakhir untuk menyampaikan aspirasi rakyat terhadap kebijakan-kebijakan yang dianggap menyimpang. ${ }^{18}$

\section{Implementasi Pasal 5 UU Nomor 9 Tahun 1998 Pasca Demonstrasi 8 Oktober 2020 di Yogyakarta}

Kebebasan mengemukakan pendapat dan berekspresi merupakan suatu kebebasan yang melekat pada setiap individu. Suatu negara dapat dikatakan sebagai negara demokrasi, jika penduduknya diberikan hak kebebasan dalam menuangkan berbagai ekspresi dan pendapatnya, baik dalam bentuk tulisan maupun lisan. Tetapi, adanya kebebasan berpendapat tersebut tentu saja sangat bergantung pada sebuah kebijakan yang telah ditetapkan oleh negara itu sendiri. Negara demokrasi tidak hanya akan memberikan hak kebebasan secara individu dalam menyampaikan ekspresinya, tetapi juga sebuah kebebasan media ekpresi untuk bebas dari intervensi.

Pada dasarnya, Negara Indonesia ini memiliki sebuah regulasi yang dapat dijadikan payung hukum yang jelas bagi masyarakatnya untuk menggunakan haknya dalam berpendapat dan menggunakan media sosial tanpa adanya intervensi. Tetapi, kebebasan berpendapat tersebut perlu juga dibatasi, agar tidak cenderung dan

18 Priyo Setyawan, "Menghadap Sultan, Forum BEM DIY Bantah Terlibat Kerusuhan 8 Oktober," iNewsYogya.id, 2 November 2020, https://yogya.inews.id/berita/menghadap-sultan-forumbem-diy-bantah-terlibat-kerusuhan-8-oktober. 
menimbulkan berbagai defamasi. Dalam Undang-Undang Dasar 1945 telah dijelaskan bahwa negara dalam menjalankan fungsinya tentu bertujuan untuk mengantarkan tujuan nasional, yang didasarkan pada sistem demokrasi. Demokrasi juga dapat dikatakan sebagai kebebasan dan persamaan. Kebebasan berpendapat di Negara Indonesia telah dijamin secara konstitusional dalam Pasal 28 Undang-Undang Dasar 1945, di sana dinyatakan bahwa "Kemerdekaan berserikat dan berkumpul, mengeluarkan pikiran dengan lisan dan tulisan, dan sebagainya ditetapkan dengan undang-undang." 19 Penjelasan lebih lanjut terkait jaminan konstitusional tersebut dijelaskan dalam Pasal 28 E ayat (3) yang berbunyi bahwa kebebasan mengeluarkan pendapat juga merupakan bagian dari hak asasi manusia. ${ }^{20}$ Selain itu, dalam Pasal 5 Undang-Undang Nomor 9 Tahun 1998 tentang Kemerdekaan Menyampaikan Pendapat di Muka Umum dijelaskan bahwa warga negara yang menyampaikan pendapat di muka umum berhak untuk (a) mengeluarkan pikiran secara bebas; (b) memperoleh perlindungan hukum. ${ }^{21}$

Mengeluarkan pikiran secara bebas merupakan suatu perbuatan yang dilakukan dengan tujuan untuk mengeluarkan pendapat, kehendak, pandangan, ataupun perasaan secara bebas dari adanya tekanan fisik, psikis, ataupun pembatasan-pembatasan yang bertentangan dengan tujuan peraturan tentang suatu kemerdekaan dalam menyampaikan pendapat di muka umum. Maka dari itu, seseorang bebas mengeluarkan pendapatnya, tetapi diperlukan suatu pembatasan agar tidak memunculkan konflik yang berkepanjangan antar anggota masyarakat.

Ada beberapa alasan yang berkaitan dengan pentingnya mengeluarkan pendapat secara bebas, yaitu (a) kebebasan berpendapat merupakan bentuk dari dasar demokrasi. (b) Kebebasan berpendapat memiliki peran dalam upaya pemberantasan tindakan

${ }^{19}$ DPR RI, “Undang-Undang Dasar Negara Republik Indonesia Tahun 1945” (Jakarta, 1945).

${ }^{20}$ DPR RI.

${ }^{21}$ DPR RI, “Undang-Undang Republik Indonesia Nomor 9 Tahun 1998 Tentang Kemerdekaan Menyampaikan Pendapat di Muka Umum," 9. 
korupsi; (c) kebebasan berpendapat juga dianggap sebagai cara terbaik dalam menemukan dan mengungkap kebenaran. ${ }^{22}$

Kebebasan berpendapat memang diperbolehkan, tetapi memiliki batasanbatasan. Batasan tersebut telah diatur dalam Undang-Undang Dasar Negara Republik Indonesia 1945, terdapat dalam jiwa (morality) masyarakat, ketertiban sosial dan politik (public order) dalam masyarakat yang demokratis. Dalam hal ini, UUD 1945 dan jiwa masyarakat merupakan suatu spirit yang membentuk kebebasan berekspresi itu tetap dipelihara dan dikembangkan dengan baik di antara mereka. Sedangkan, ketertiban sosial dan politik merupakan suatu norma, etika, ataupun berbagai hal lain yang memang menjadi kebiasaan dalam kehidupan masyarakat yang demokratis.

Demonstrasi yang dilakukan oleh masyarakat sipil dan mahasiswa merupakan suatu gerakan moral tanpa adanya pemaksaan kehendak. Massa aksi memang seringkali tidak menyadari bahwa ada pihak-pihak luar yang menumpang kepentingan dalam gerakan moral tersebut. Untuk menghadapi pihak-pihak tersebut yang telah bergabung dan membaur dengan massa aksi, akan sulit untuk dikendalikan saat mereka melakukan tindakan anarkis. Akibatnya, banyak demonstrasi yang pada mulanya merupakan sebagai aksi damai namun berubah menjadi gerakan pemaksaan kehendak dan berakhir dengan kericuhan. Selain adanya penyusupan di antara massa aksi tersebut, ada hal lain seperti kebijakan atau perlakuan pemerintahan yang menjadi sasaran demonstrasi tersebut menolak untuk menerima dan tidak adanya dialog antara massa aksi dan pihak pemerintahan. $^{23}$

Demonstrasi massa buruh, aktivis dari berbagai organisasi, masyarakat sipil, dan mahasiswa yang tergabung dalam demonstrasi 8 Oktober 2020 di Yogyakarta merupakan salah satu bentuk dalam penyampaian aspirasi rakyat dalam penolakan UU Omnibus Law yang telah disahkan oleh DPR RI. Majelis Pekerja Buruh Indonesia (MPBI) Daerah Istimewa Yogyakarta telah mendukung penolakan UU Omnibus Law

22 Supriyadi W.E dan Ririn Sjafriani, Kontroversi Undang-Undang ITE: Menggugat Pencemaran Nama Baik di Ranah Maya (Jakarta: Degraf Publishing, 2010), 11.

${ }^{23}$ Abdussalam, Kemerdekaan Menyampaikan Pendapat di Muka Umum (Jakarta: Restu Agung, 2006), 289. 
tersebut dengan melakukan aksi mogok nasional pada tanggal 6-8 Oktober 2020. Anggota MPBI dari konfederasi Serikat Pekerja Seluruh Indonesia (KSPSI) DIY, ikut serta dengan Aliansi Rakyat Bergerak dalam melakukan demonstrasi 8 Oktober 2020 lalu. Pada mulanya, aksi tersebut dilakukan dengan cara long march yang dimulai dari kawasan Tugu menuju Kantor DPRD DIY, dan sekitar Kompleks Kantor Gubernur di kawasan Jalan Malioboro Yogyakarta. ${ }^{24}$

Demonstrasi ini digelar dengan tujuan awal untuk menyadarkan pihak pemerintahan atas apa yang mereka lakukan. Dengan pengesahan UU Omnibus Law tersebut tentu pemerintah telah banyak menyimpang dari kedaulatan rakyat. Maka dari itu, seharusnya pemerintah melaksanakan dan menerima apa yang menjadi tuntutan rakyat. Bila pemerintah sendiri melaksanakan tuntutan rakyat, maka tidak akan ada dampak negatif yang terjadi. Dalam pandangan Islam, Islam tidak pernah mengajarkan kepadanya umatnya untuk dapat melakukan sebuah kerusakan di muka bumi. Demonstrasi pada tanggal 8 Oktober 2020 di Yogyakarta, bisa dikatakan sebagai demonstrasi anarkis. Massa aksi dalam penolakan UU Cipta Kerja Omnibus Law ini telah merusak berbagai fasilitas di sekitar Gedung DPRD DIY, fasilitas umum, bahkan terjadinya pembakaran Legian Resto. Perbuatan tersebut telah bertentangan dengan nas yang melarang adanya perusakan dan mengancamnya dengan hukuman. Allah Swt berfirman dalam QS. Al-A'raf ayat 56, yaitu:

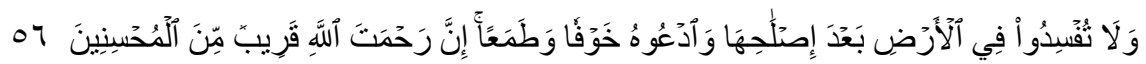

Artinya: "Dan janganlah kamu membuat kerusakan di muka bumi, sesudah (Allah) memperbaikinya dan berdoalah kepada-Nya dengan rasa takut (tidak akan diterima) dan harapan (akan dikabulkan). Sesungguhnya rahmat Allah amat dekat kepada orang-orang yang berbuat baik," (QS. Al-A'raf (7): 56).

Adanya undang-undang tidak menjamin pelaksanaan demonstrasi menjadi tertib. Pada praktiknya, demonstrasi seringkali tidak dapat dikenalikan sehingga berujung pada tindak kekerasan serta kerusuhan massa yang akan mengganggu ketertiban umum, salah

24 CNN Indonesia, "Buruh Yogyakarta Dukung Aksi Mogok Nasional 6-8 Oktober," cnnindonesia.com, Oktober 2020. 
satunya adalah demonstrasi yang terjadi pada tanggal 8 Oktober 2020 di Yogyakarta. Kerusuhan massa aksi sendiri terjadi atas adanya lima prasyarat yang secara bertahap harus dipenuhi, yaitu adanya tekanan tertentu, situasi sosial yang akhirnya menimbulkan kerusuhan, mobilisasi massa untuk beraksi, berkembangnya banyak prasangka kebencian, dan adanya kontrol sosial yang memang dikendalikan oleh para aparat keamanan. ${ }^{25}$

Jika ditelaah dari teori mas\}lah\}ah, tentu saja demonstrasi yang terjadi di Yogyakarta pada saat itu sangat bertentangan, karena menyebabkan kerusakan, kesakitan, dan keburukan. Karena dalam sebuah mas\}lahłah dan mafsadah yang masyru' (legal), dampaknya tentu tidak dapat dipisahkan antara tujuan dunia maupun tujuan akhirat. Namun, dampak yang terjadi di dunia akan selalu mempengaruhi kehidupan di akhirat. ${ }^{26}$

\section{Analisis Mas\}lah\}ah dalam Memandang Pelarangan Demonstrasi oleh Sultan Hamengku Buwono X}

Telah dijelaskan dalam Pasal 5 Undang-Undang Nomor 9 Tahun 1998 Tentang Kemerdekaan Menyampaikan Pendapat bahwa warga negara yang menyampaikan pendapat di muka umum berhak untuk: (a) mengeluarkan pikiran secara bebas; (b) memperoleh perlindungan hukum. ${ }^{27}$ Dalam Pasal 5 Undang-Undang Nomor 9 Tahun 1998 ini sudah sangat jelas bahwa setiap warga negara memiliki hak untuk mengeluarkan pendapatnya, baik secara lisan maupun tulisan; serta memiliki hak untuk memperoleh perlindungan hukum terkait hal tersebut.

Pasca terjadinya demonstrasi 8 Oktober 2020 di Yogyakarta, Sultan Hamengku Buwono X telah mengeluarkan sebuah pernyataan sebagai tanggapannya terhadap aksi demonstrasi tersebut yang berisi, "Yogyakarta dengan masyarakatnya tidak pernah

${ }^{25}$ N.J. Smelser, Theory of Collective Behaviour (Jakarta: Yayasan Obor Indonesia, 2020), 237.

26 Ahmad Raisuni, Nadzriyyah al-Maqashid 'inda al-Imam asy-Syatibi, 4 ed. (Riyadh: Dar al'Alamiyyah li al-Kuttab al-Islamiyyah, 1995), 257.

${ }^{27}$ DPR RI, “Undang-Undang Republik Indonesia Nomor 9 Tahun 1998 Tentang Kemerdekaan Menyampaikan Pendapat di Muka Umum." 
mempunyai itikad untuk membangun anarki, untuk aktivitas yang dilakukan oleh kelompok-kelompok masyarakat. Saya Hamengku Buwono X mengimbau dan berharap kepada kelompok-kelompok masyarakat, bukan karakter kita untuk berbuat anarkis di kotanya sendiri." 28

Menyampaikan pendapat di muka umum yang bertujuan untuk kebaikan memang sangat dianjurkan. Namun dalam pelaksanaannya, ada hukum yang membatasi hal tersebut. Pembatasan ini bertujuan untuk menertibkan kegiatan apapun tanpa menimbulkan suatu kerugian. Dengan adanya peringatan yang dilontarkan oleh Sri Sultan Hamengku Buwono $\mathrm{X}$ bukan tanpa adanya sebab dan pertimbangan. Dalam pernyataan itu, Sri Sultan Hamengku Buwono X tentu telah mempertimbangkan dampak-dampak positif untuk masyarakat sekitar DIY Yogyakarta. Peringatan tersebut jika ditelaah lebih lanjut, tidak secara utuh bertujuan untuk melarang pelaksanaan demonstrasi yang digunakan sebagai media dalam menyampaikan aspirasi dan pendapat rakyat kepada rakyatnya. Tetapi, pernyataan Sri Sultan Hamengku Buwono X tersebut dapat dimaknai sebagai wujud penyampaian pendapat yang masih diperbolehkan, tetapi dalam pelaksanaannya tentu harus secara tertib dan tidak menimbulkan kerusuhan, perusakan fasilitas-fasilitas umum, kekerasan, mencemaskan dan merugikan warga Yogyakarta.

Jika ditinjau dari teori mas\}lah\}ah, himbauan yang dikeluarkan oleh Sultan Hamengku Buwono X ini dinilai tidak melanggar Pasal 5 Undang-Undang Nomor 9 Tahun 1998, serta dianggap tidak melanggar hukum Islam yang telah membatasi kebebasan seseorang dalam mengeluarkan pendapatnya. Hal ini didasarkan karena aksi demonstrasi yang dilakukan pada tanggal 8 Oktober 2020 di Yogyakarta tersebut telah bertentangan dengan hukum Islam sendiri. Dalam pelaksanaan demonstrasi tersebut, ada beberapa catatan yang dinilai bertentangan dengan hukum Islam, yaitu pertama, adanya pencelaan yang dilakukan massa aksi terhadap pemimpin, dengan menyebarkan keburukan seorang pemimpin tersebut. Menurut Abu 'Ukaim, kejelekan seorang

28 Bagus Kurniawan, "Ini Pernyataan Sultan HB X Soal Demo Ricuh di Yogyakarta," Portaljogja.com, Oktober 2020, https://portaljogja.pikiran-rakyat.com/yogyaistimewa/pr-25813950/inipernyataan-sultan-hb-x-soal-demo-ricuh-di-yogyakarta. 
pemimpin itu merupakan kunci untuk dapat menumpahkan darahnya. ${ }^{29}$ Allah Swt berfirman dalam QS. Al-Ahzab ayat 58, yaitu:

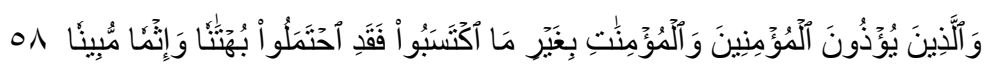

Artinya: "Dan orang-orang yang menyakiti orang-orang yang mukmin dan mukminat tanpa kesalahan yang mereka perbuat, maka sesungguhnya mereka telah memikul kebohongan dan dosa yang nyata," (QS. Al-Ahzab (33): 58).

Kedua, perbuatan tersebut mengutamakan hawa nafsu. Hal ini juga dijelaskan oleh Allah Swt dalam QS. Ar-Rum ayat 31-21, yaitu:

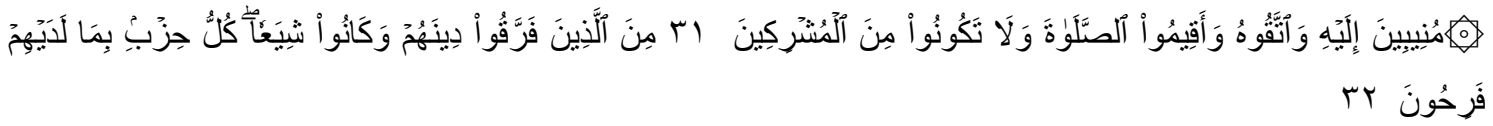

Artinya: "(31) Dengan kembali bertaubat kepada-Nya dan bertakwalah kepada-Nya serta dirikanlah shalat dan janganlah kamu termasuk orang-orang yang mempersekutukan Allah, (32) yaitu orang-orang yang memecah-belah agama mereka dan mereka menjadi beberapa golongan. Tiap-tiap golongan merasa bangga dengan apa yang ada pada golongan mereka," (Ar-Rum (30): 31-32).

Ketiga, hilangnya sebuah keamanan dan ketenteraman masyarakat umum. Menurut Imam al-Mawardi, ada enam faktor yang dapat menjadikan dunia itu aman, yaitu pemimpin yang kuat, agama, keamanan yang merata, keadilan yang menyebar, semangat tinggi, serta adanya kesuburan tanaman. ${ }^{30}$ Keempat, banyaknya kerusakan pada fasilitas-fasilitas umum, jalan-jalan, kendaraan, rumah makan yang dibakar, merugikan diri sendiri bahkan orang sekitar. Kelima, demonstrasi tersebut telah mengakibatkan kemacetan. Setiap aksi demonstrasi, tentu akan mengakibatkan kemacetan. Sehingga, seringkali menghambat keperluan orang lain, baik keperluan orang-orang yang akan bekerja, perjalanan darurat, seperti yang dilakukan oleh mobil ambulans rumah sakit, mobil pemadam kebakaran, atau kendaraan lain yang sifatnya darurat. Hal ini telah dijelaskan oleh Allah Swt dalam QS. Al-Ahzab ayat 58, yaitu:

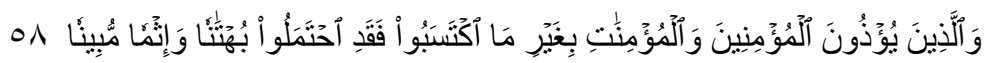

\footnotetext{
${ }^{29}$ Abu Ubaidah Yusuf, Demonstrasi Solusi atau Polusi (Bogor: Pustaka Darul Ilmi, 2009), 48.

${ }^{30}$ Abu Ubaidah Yusuf, 68.
} 
Artinya: "Dan orang-orang yang menyakiti orang-orang yang mukmin dan mukminat tanpa kesalahan yang mereka perbuat, maka sesungguhnya mereka telah memikul kebohongan dan dosa yang nyata," (QS. Al-Ahzab (33): 58).

Menurut analisis mas\}lah\}ah berdasarkan pada Pasal 5 Undang-Undang Nomor 9 Tahun 1998, peringatan Sri Sultan Hamengku Buwono X ini dinilai boleh dan dianggap sah. Hal ini disebabkan, himbauan yang diberikan oleh Sultan tidak bertentangan dengan syariat Islam dan tidak pula mencederai Pasal 5 Undang-Undang Nomor 9 Tahun 1998. Menurut pandangan al-Qardawi, adanya kaidah hukum Islam inna al-as lla $f i>$ al-asyya>'il al-iba>h\}ah, yaitu hukum asal dalam segal hal itu diperbolehkan, kecuali ada nas yang menyatakan sebaliknya. Al-Qardawi juga berpendapat bahwa adanya demosntrasi itu diperbolehkan dalam Islam selama tujuannya baik dan di dalamnya tidak mengandung unsur-unsur yang dianggap bertentangan dengan syariat Islam. ${ }^{31}$

Himbauan yang dikeluarkan oleh Sri Sultan Hamengku Buwono X ini dinilai tidak melanggar selama tujuan dari himbauan tersebut untuk menegakkan amar makruf nahi mungkar, sebagai sebuah metode untuk mengontrol kekuasaan demi terciptanya kemaslahatan masyarakat, serta dalam praktiknya tidak bertentangan dengan syariat Islam. Allah Swt berfirman dalam QS. Al-Hajj ayat 40-41, yaitu:

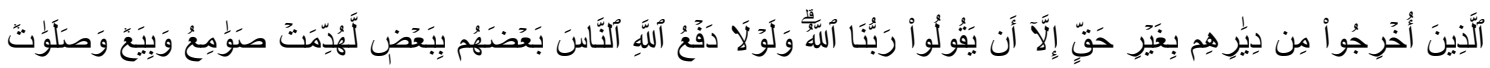

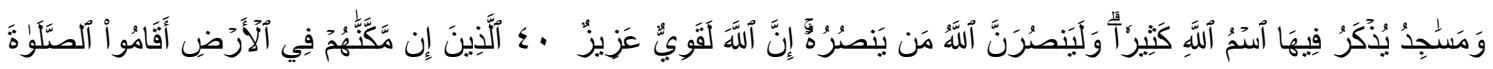

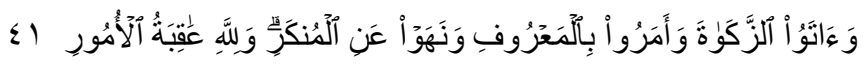
Artinya: "(40) (yaitu) orang-orang yang telah diusir dari kampung halaman mereka tanpa alasan yang benar, kecuali karena mereka berkata: "Tuhan kami hanyalah Allah". Dan sekiranya Allah tiada menolak (keganasan) sebagian manusia dengan sebagian yang lain, tentulah telah dirobohkan biara-biara Nasrani, gereja-gereja, rumah-rumah ibadat orang Yahudi dan masjidmasjid, yang di dalamnya banyak disebut nama Allah. Sesungguhnya Allah pasti menolong orang yang menolong (agama)-Nya. Sesungguhnya Allah benar-benar Maha Kuat lagi Maha Perkasa, (41) (yaitu) orang-orang yang

${ }^{31}$ Ija Suntana, Pemikiran Ketatanegaraan Islam (Bandung: Pustaka Setia, 2010), 62. 
jika Kami teguhkan kedudukan mereka di muka bumi niscaya mereka mendirikan sembahyang, menunaikan zakat, menyuruh berbuat ma'ruf dan mencegah dari perbuatan yang mungkar; dan kepada Allah-lah kembali segala urusan," (QS. Al-Hajj (22): 40-41).

Maka dari itu, dapat disimpulkan bahwa himbauan yang dikeluarkan oleh Sri Sultan Hamengku Buwono X pasca terjadinya demonstrasi pada tanggal 8 Oktober 2020 tersebut, jika dianalisis dalam perspektif mas\}lahłah dapat dibenarkan karena adanya pertimbangan banyak hal, salah satunya adalah ketertiban, penjagaan terhadap fasilitas-fasilitas umum, serta untuk menjaga keamanan sekitar. Himbauan ini jangan dimaknai secara kontekstual saja, melainkan harus melihat maknanya dari sisi lain. Sesungguhnya, peringatan ini lahir bukan bertujuan untuk membatasi, menghilangkan hak-hak masyarakat, bahkan melarang mereka untuk menyampaikan aspirasinya. Tetapi, adanya himbauan Sri Sultan Hamengku Buwono X ini bertujuan untuk memperingati warganya agar tetap mengikuti peraturan yang ada, berlaku tertib dalam melakukan demonstrasi, bertanggung jawab atas apa yang telah diperbuat, dan tidak melakukan kerusuhan, perusakan fasilitas umum, dan membuat warga Yogyakarta merasa terancam keamanannya. Dalam perspektif mas\}lah\}ah, hal ini tentu sangat dibenarkan karena bertujuan untuk meminimalisir kemudaratan dan menegakkan kemaslahatan bersama.

\section{Penutup}

Berdasarkan penjelasan di atas dapat disimpulkan bahwa menurut perspektif mas\}lah\}ah, demosntrasi dihukumi boleh, tetapi harus dilakukan dengan tertib dan tidak bersifat anarkis, melakukan tindakan yang meresahkan warga, melakukan perusakan terhadap fasilitas umum, dan bertentangan dengan syariat Islam. Sedangkan, himbauan yang dikeluarkan oleh Sri Sultan Hamengku Buwono X pasca terjadinya demonstrasi pada 8 Oktober 2020 di Yogyakarta tidak bertentangan dengan hukum Islam, juga tidak melanggar apa yang telah dituangkan dalam Pasal 5 Undang-Undang Nomor 9 Tahun 1998 Tentang Kemerdekaan Menyampaikan Pendapat di Muka Umum. Oleh karena itu, dalam himbauan tersebut tidak ada sebuah pelarangan demonstrasi dalam upaya untuk 
menyampaikan pendapat. Tetapi, peringatan yang dikeluarkan oleh Sri Sultan Hamengku Buwono $\mathrm{X}$ tersebut sebagai bentuk himbauan kepada masyarakat Yogyakarta untuk tetap menjaga tata tertib, keamanan, dan menghindari tindakan anarkis yang dapat meresahkan warganya dalam melakukan aksi demonstrasi di wilayah Yogyakarta.

\section{Referensi}

Abdul Haq. Formulasi Nalar Fiqh Telaah Konseptual. Surabaya: Khalista, 2006.

Abdussalam. Kemerdekaan Menyampaikan Pendapat di Muka Umum. Jakarta: Restu Agung, 2006.

Abu Ubaidah Yusuf. Demonstrasi Solusi atau Polusi. Bogor: Pustaka Darul Ilmi, 2009.

Ahmad Raisuni. Nadzriyyah al-Maqashid 'inda al-Imam asy-Syatibi. 4 ed. Riyadh: Dar al-'Alamiyyah li al-Kuttab al-Islamiyyah, 1995.

Bagus Kurniawan. "Ini Pernyataan Sultan HB X Soal Demo Ricuh di Yogyakarta." Portaljogja.com. Oktober 2020. https://portaljogja.pikiranrakyat.com/yogyaistimewa/pr-25813950/ini-pernyataan-sultan-hb-X-soal-demoricuh-di-yogyakarta.

Budiman Tanuredjo. Pasung Kebebasan: Menelisik Kelahiran Undang-Undang Unjuk Rasa. Jakarta: Lembaga Studi dan Advokasi Masyarakat (ELSAM), 1991.

CNN Indonesia. "Buruh Yogyakarta Dukung Aksi Mogok Nasional 6-8 Oktober." cnnindonesia.com, Oktober 2020.

DPR RI. “Undang-Undang Dasar Negara Republik Indonesia Tahun 1945.” Jakarta, 1945.

—. "Undang-Undang Republik Indonesia Nomor 9 Tahun 1998 Tentang Kemerdekaan Menyampaikan Pendapat di Muka Umum.” Jakarta, 1998.

Ija Suntana. Pemikiran Ketatanegaraan Islam. Bandung: Pustaka Setia, 2010.

Kompas. "Mengungkap Fakta Restoran Legian di Malioboro Terbakar Saat Kerusuhan di DPRD DIY." Kompas.com. Oktober 2020. https://yogyakarta.kompas.com/read/2020/10/10/14400091/mengungkap-faktarestoran-legian-di-malioboro-terbakar-saat-kerusuhan-di?page=all.

Kumparan. "Daftar Kerusakan Demo Yogya: Cafe Terbakar hingga Mobil Polisi." Kumparan NEWS, Oktober 2020. https://kumparan.com/kumparannews/daftarkerusakan-demo-yogya-cafe-terbakar-hingga-mobil-polisi-1uLvpTwRUmQ.

Muhamamd Fakhrur Razy dan Muhammad Fedryansyah. "Konflik Gerakan Masyarakat Sipil dan Pemerintah dalam Proses Penyusunan Rancangan Undang Undang Omnibus Law.” Jurnal Kolaborasi Resolusi Konflik 2, no. 2 (2020). 
Muhamamd Gazali Rahman. "Unjuk Rasa Versus Menghujat (Analisis Deskriptif Melalui Pendekatan Hukum Islam)." Jurnal Hunafa: Jurnal Studia Islamika 122, no. 2 (Desember 2015).

Muhammad Aminullah. "Demonstrasi dalam Perspektif Hadis." Jurnal El-Hikam: Jurnal Pendidikan dan Kajian Keislaman VII, no. 2 (Juli 2014).

Mustafa Zaid. Al-Maslahah fi al-Tasyri' al-Islami wa Najm ad-Din at-Tufi. Beirut: Dar al-Fikr al-Arabiy, 1974.

N.J. Smelser. Theory of Collective Behaviour. Jakarta: Yayasan Obor Indonesia, 2020.

Priyo Setyawan. "Menghadap Sultan, Forum BEM DIY Bantah Terlibat Kerusuhan 8 Oktober." iNewsYogya.id. 2020. https://yogya.inews.id/berita/menghadap-sultan-forum-bem-diy-bantah-terlibatkerusuhan-8-oktober.

Siti Tatmainul Qulub. "Batasan Kebebasan Berpendapat dalam Menyampaikan Argumentasi Ilmiah di Media Sosial Perspektif Hukum Islam." Jurnal AlJinayah: Jurnal Hukum Pidana Islam 4, no. 2 (Desember 2018).

Supriyadi W.E dan Ririn Sjafriani. Kontroversi Undang-Undang ITE: Menggugat Pencemaran Nama Baik di Ranah Maya. Jakarta: Degraf Publishing, 2010.

Tribun Jogja. "Demo Omnibus Law di Yogyakarta, Pernyataan Sri Sultan HB X Hingga Sikap Warga Kecam Aksi Anarkis.” Jum'at, Oktober 2020. https://jogja.tribunnews.com/2020/10/09/demo-omnibus-law-di-yogyakartapernyataan-sri-sultan-hb-x-hingga-sikap-warga-kecam-aksi-anarkis?page $=4$.

. "Pesan Sri Sultan Hamengku Buwono X: Kalau Mau Demo, Silahkan. Asal, Tidak Melakukan Perusakan." TribunJogja.com. 24 September 2019. https://jogja.tribunnews.com/2019/09/24/pesan-sri-sultan-hamengku-buwono-Xkalau-mau-demo-silahkan-asal-tidak-melakukan-perusakan.

Ujang Chandra S. "Hakikat Hak Kebebasan Menyampaikan Pendapat di Muka Umum." Jurnal Komunikasi Hasil Pemikiran dan Penelitian 3, no. 1 (April 2017).

Yahya Khusnan Mansur. Ulasan Nazam Qawaid Fiqhiyyah al-Faraid al-Bahiyyah. Tambak Beras Jombang: Pustaka al-Muhibbin, 2009.

Zaenal Abidin Eko Putro. "Ketahanan Toleransi Orang Jawa: Studi Tentang Yogyakarta Kontemporer.” Jurnal Sosiologi 15, no. 2 (Juli 2010). 